\title{
What Kind of Leadership do we Need at Schools for Effective Teachers?
}

\author{
Msc. Stavroula Siatira
}

\author{
Secondary School Teacher, 3rd Lyceum of Karditsa, Karditsa, Greece; stsiatira@sch.gr
}

\section{Doi:10.5901/ajis.2015.v4n3s1p115}

\begin{abstract}
This article focuses on exploring the characteristics of leadership at schools and the policy of a School Principal that can drive teachers to be effective. It focuses most on recording what is important for school leadership and in what way and with what energies and behaviours a School Principal could affect teaching staff in their daily work. A person with values, vision and strategy seems to be the right person in the right place. Also, key factor at schools is the way that a School Principal thinks and acts, with stability, determination, participatory approach and great professionalism. The research demonstrates that especially the incentive policy of a School Principal has a strong motivating influence on the teachers' daily work. We have to realize that successful school leadership can contribute to the creation of the necessary conditions, which could improve the teaching staff and their efficacy for better performance and the success of school, their workplace.
\end{abstract}

Keywords: Leadership, School Principal, Teaching Staff, Incentive Policy.

\section{Introduction}

Human organizations are considered as functional "systems", containing a number of interdependent and interacting components-parts and they are characterized by complex processes and complex organizational structures (Senge, 2006). It is necessary for these organizations to detect signals from their environment (internal and external) and adapt accordingly. The only sustainable competitive advantage is their ability to learn quickly. Parsons (2008, pp. 80-85) perceives the school as a system and gives a definition according to which an educational system is defined as a sum of parts with dynamic relationship and interdependence of its components. The function of the parts is different from the operation of the whole. These parts are called subsystems and they are systems within the system itself. School Principal and teaching staff are subsets within the school system.

For every organization leadership is one important factor that brings to it competitive advantages and success (Carey et al., 2011). An effective leader has the ability to motivate his/her staff (Dan-Shang \& Chia-Chun, 2013) and his/her style of leadership and strategies can determine staff's motivation (De Meuse et al., 2011) by using their skills and resources to achieve goals (Limbrare, 2012). A leader can envision future needs and empower the staff to share and implement a vision. Especially, education leadership is the factor that helps to the creation of an effective school environment (Kelley et al., 2005). Considering the important role of school leadership and under the view of interdependent systems within the school system and specific about the subsystems of School Principal and teaching staff, it is important to consider four parameters. Firstly, the personality of a School Principal; secondly, the incentive policy a School Principal follows to motivate the teachers of the school unit that he/she manages; thirdly, the School Principal's ability to affect the development of human resources, the professional development of the teaching staff in the school unit that he/she manages and how; fourthly, a School Principal is potential to affect the efficacy and the daily performance of the teaching staff in the school unit that he/she manages.

\section{Leadership Styles}

The way an individual motivates and influences others is leadership (Limbare, 2012). As it has been argued, there is no one leadership style that is suitable for any particular organization. As circumstances (internal, external, market) change, an organization adapts the style of leadership that is best suited. So different management or different leadership styles seem to be broadly suited to a particular business form or structure, but there will be times when the style is easily transferable to organizations that have previously been run in quite different ways (Pawar, 2014). Styles of leadership that we meet at leadership literature are autocratic leader, directive leadership, constitutional or participative leader, missionary leadership, laissez faire leadership and paternalistic. Autocratic leader is an effective one when he/she relies 
upon a hierarchical organizational structure and when quick restructuring is required (Van Vugt et al., 2004; Pawar, 2014). Results from a scenario experiment and an organizational survey indeed showed that distributive justice and autocratic leadership style interacted to influence followers' negative emotions such that the relationship between distributive justice and negative emotions was significant when the leadership style was low in autocratic behaviour. Implications in terms of integrating the leadership and justice are discussed in literature (De Cremer, 2007). Directive leader is a supervisor. He/she makes clear the role and tasks of staff and what expects of it without bringing motivation of staff (Somech, 2005).

Constitutional or participative leader consults with subordinates in the decision making process (Peterson, 1997; Somech, 2005). Missionary leadership is the one that a leader is driven by his/her beliefs. It is important for that style of leadership the leader has an organization and employees behind him/her that also have the same set of beliefs (Thiagarajan, 2003). The laissez faire leadership is the one that leader leaves the staff to be well alone. The power to make decisions and all the rights is given to staff. It has freedom to make decisions and achieve the completion of its work. The leader gives them all the support and materials that are necessary materials accomplishing their goals but he/she doesn't involve them in decision making process unless they ask for it (Eagly, 2003; Goodnight, 2004). Finally, the paternalistic leader is the one that works by acting as a father/mother figure by taking care of their subordinates as a parent and takes concern for staff and in return receives trust and loyalty (Pellegrini \& Scandura, 2008). Bass (1985) at his book "Leadership and Performance beyond Expectations" argues that workers who follow paternalistic leadership have better organization skills. Staff completes its tasks with self-confidence and works hard to reach goals (Pawar, 2014).

Also, in leadership literature it was been found two common leadership styles: transformational and transactional. The first one the transformational leadership is a style that has positive impact on employees views and goals (Eagly, 2003; Wright et al., 2012). A transformational leader motivates staff to understand and support his/her decisions (Sahaya, 2012). He/she creates strength on individuals and team, which produce increased staff's performance (Birasnav et al., 2010). He/she can motivate staff (Wright et al., 2012) and share in decision-making process and objectives with them (Hoffman et al., 2011; Riggio et al., 2003). According to the expectancy theory, a leader would share in the decisionmaking process and maintain collaboration with staff. The staff's behaviour is as important as leader's behaviour (Vroom, 1964). Also, according to the decision theory, individuals' ethics, principles, behaviours determine their decisions (Scheibehenne et al., 2011). In addition, transactional leadership style consists of rewarding staff for their performance (Eagly, 2003; Sahaya, 2012) when they achieve certain goals (Zhu et al., 2012). Since this is a reward-based system, the effectiveness of this leadership style may be short-lived (Sahaya, 2012).

Also, conserning Principal leadership the instructional leadership construct exists in the literature and there is interest about it. In literature instructional leaders are described as strong, directive leaders who have success at "turning their schools around" (Bamburg \& Andrews, 1991; Bossert et al., 1982; Hallinger \& Murphy, 1986). Hallinger (2005, p. 234) by broad reading of the literature on instructional leadership over the past twenty-five years presents that the instructional leader must focus on creating a shared sense of purpose in the school, including clear goals focused on student learning; fostering the continuous improvement of the school through cyclical school development planning that involves a wide range of stakeholders; developing a climate of high expectations and a school culture aimed at innovation and improvement of teaching and learning; coordinating the curriculum and monitoring student learning outcomes; shaping the reward structure of the school to reflect the school's mission; organizing and monitoring a wide range of activities aimed at the continuous development of staff; and being a visible presence in the school, modeling the desired values of the school's culture. It must be noted that the instructional leadership model has often been interpreted as being topdown and directive. Lambert (2002, p. 37) contends that, "The days of the lone instructional leader are over". Hallinger (2005, p. 235) writes about the most ambitious attempt to study shared instructional leadership empirically which was undertaken by Marks and Printy (2003). This study suggests that strong transformational leadership by the Principal is essential in supporting the commitment of teachers. When teachers perceive Principals' instructional leadership behaviours to be appropriate, they grow in commitment, professional involvement, and willingness to innovate. Thus, instructional leadership can itself be transformational.

Finally, needs of organizations provide the varying definition of leaderships. As circumstances change, so do the types of leadership require change (De Meuse et al., 2011). It is clear that leadership behaviours and strategies used by leaders are vital for organizations and for organizational success (Kawar, 2012). 


\section{School Principal: Characteristics and Tasks}

In almost all studies on schools' effectiveness one of the clearest messages is that the capable leadership of School Principal is an important factor (Gray, 1990; Leithwood \& Riehl, 2005). Studying the educational leadership literature, we realize that different leadership styles are associated with the effectiveness of schools and there is a wide range of views on the capable leadership in school. The term capable leadership includes three keywords: values, vision and strategy (Frost \& Durrant, 2003). Remarkable values in a leader such us honesty and integrity are virtues in all individuals, but have special significance for leaders. Integrity is the correspondence between word and deed and honesty refers to being truthful or not-deceifful. They two form the foundation of a trusting relationship between leader and staff. Also, selfconfidence is needed in decision-making and in gaining others' trust. There are many reasons why a leader needs selfconfidence. For example, a great deal of information must be gathered and processed, series of problems must be solved and decisions made, setbacks have to be overcome, competing interests to be satisfied, risks may be omitted. Emotional stability is especially important when resolving interpersonal conflicts and when representing the organization. Successful leaders are calm, confident, and predictable during crisis. Cognitive ability is necessary to gather, integrate, and interpret information. Intelligence may be a trait that staff looks for in a leader. Close to all these effective leaders have a high degree of knowledge. A leader has often been characterized as being intelligent and as being conceptually skilled (Kirkpatric \& Lock, 1991).

Regarding vision it must be underlined that when a leader has a clear vision he also needs the ability to persuade staff to work towards achieving that vision (Birasnav et al., 2010). A vision is a target that beckons. A leader must communicate this to staff through speeches, written messages, through acting as a role model and personally acting in a way that is consistent with the vision. To implement a vision at least six activities are required: structuring, selecting and training, motivating, managing information, team building and promoting change and innovation. Effective leaders must promote change and innovation. A vision is a starting point of change. Change must be reinforced by constant restructuring, continual retraining to develop new skills, setting specific goals for innovation and improvement, rewarding innovation, encouraging constant information flow in all directions. For implementing a vision a leader must develop a strategy (Kirkpatric \& Lock, 1991). Organizations and companies executives develop strategies to meet goals. Strategies are critical for their sustainability (Bonn \& Fisher, 2011) and determine what resources to utilize to implement visions (Kalyani \& Sahoo, 2011). Strategies require leaders to think critically. Questions are needed to develop strategies. They are about what the objectives are, what the measure of success is, how the strategy can be implemented.

Also, in most researches three seem to be in high frequency the characteristics of a successful School Principalleader; stability and determination, participatory approach and top professionalism. In particular, regarding the first characteristic, stability and determination of School Principal, it should be noted that it is considered a key factor for change in factors related to school life (Gray, 1990). The School Principal is the one who tries to improve processes, driven by external factors, such as the Ministry of Education (Weindling, 1989), and maintains these changes. So, the skilful leadership of school unit is a key factor that explains the successful change and improvement (Berry et al., 2008; Hallinger, 2003; Leithwood \& Sleegers, 2006; Supovitz \& Turner, 2000). Regarding the second feature, the participatory approach, it is highly advisable for the School Principal to distribute responsibilities in school to assistants or even to involve teaching staff in decisions related to school subjects, such as school planning (Smith \& Tomlinson, 1990). The decision-making process and the existence of a positive climate in school unit, created and supported first of all by the School Principal, contribute to its efficiency (Berry et al., 2008; Coleman \& Collinge, 1991; Saitis 2008, p. 34). But it needs careful judgment about what cases of decision-making should be done by the one and what is good to involve others. Finally, on the third feature, the top professionalism, it is noted that it is a powerful tool for bringing changes to a business or an organization and social control. The professionalism must be based on strong professional identity, ability, cooperation and trust (Evetts, 2005). It is regarded as an important and highly desirable value at which relations are characterized as collective, cooperative and solid.

It must be clear that School Principal performs a series of tasks-activities. In the literature these are divided into formal and informal/unofficial (Clemson-Ingram \& Fessler, 1997; Harris, 2003). These two terms must be clarified and distinquished. About the first, the formal, it must be mentioned that they have to do with official leadership roles relating to accountability, decision making concerning the animate and inanimate material of a school unit, coordinating and overseeing all operations and, therefore, the School Principal abstains from the classroom and teaching duties in order to carry out its leadership duties. About the second term, the informal/unofficial duties of a School Principal, it should be mentioned that they relate to activities involving the classroom, such as design, achieving communication objectives, setting activities, creating a pleasant environment in the workplace for school units' staff (Ash \& Persall, 2000; Harris, 
2003). A School Principal needs to know what happens in the classroom, curricula, curriculum and monitoring pupils' progress (Mortimore et al., 1988). Also, he/she needs to support teachers, gives encouragement and practical help to them. He/she needs to supervice the school grounds and visit the classrooms and the classes (Teddlie et al., 1989). The School Principal has always been expected to perform a variety of roles. For example, identified political, managerial and instructional roles. As a conclusion, School Principal's effectiveness is attained by finding the correct balance among these roles (Hallinger, 2005, p. 222).

\section{School Principal and Teaching Staff}

Enough evidence is available about the effect of School Principal on the motivation of teaching staff and teachers' additional efforts payment (Geijsel et al., 2003; Nguni et al., 2006; Ross \& Gray, 2006). Considering the data from these studies regarding the motivation of teachers regarding teaching and learning practices it has been found that their involvement in professional learning activities and teaching practices is related to the incentives offered to them (Thoonen et al., 2011). Motivation by the School Principal for teachers and support for what their professional development needs bring positive attitude of teachers towards the School Principal and affect their work in the classroom (Siatira et al., 2014). Strategies of School Principal have strong "booster effect" on teachers, emotionally, mentally and behaviourally (Blase \& Blase, 2000).

Dimension of School Principal's practice includes actions relating to development objectives related to school life and inspire a vision for the future. First are the determination and the structure of a vision. The School Principal assists the development and approval of visions that embody the best ideas for teaching and learning and inspire teaching staff to achieve ambitious goals (Leithwood \& Riehl, 2005; Nguni et al., 2006). Second, he/she promotes the development of common concepts that support common visions, since people usually base their actions on the way they perceive things. Legitimacy and effectiveness are enhanced when both parties, members of the school unit and the wider society share clear conceptions regarding the pupils, learning and school life. Thirdly, School Principal creates expectations for high performance and carries out expectations for quality and high performance. The positive expression of high expectations helps people realize that what is expected is actually feasible. Fourth, a School Principal must support team goals. School Principal should promote cooperation and joint effort to achieve objectives, emphasizing the value of collective goals and cooperation. It should be noted that if there is consistency between school units' teachers, they feel more committed and are more willing to adopt common goals and values (Thoonen et al., 2011). Fifth, it is necessary for a School Principal to control the performance of school unit. A School Principal monitors the operation and performance in different fields, collects and interprets information, creating a tradition in research and reflection. It is good for School Principal to be communicative, since communication strategies influence decision making processes (Leithwood \& Riehl, 2005).

It has been argued that for an effective relationship-interaction between school Principal and teachers in the educational process reflection, research, experimentation, results are required. Two major issues that must be notified are firstly to strengthen the discussion between School Principal and teachers, so there is feedback, and, secondly, to promote the professional development of teachers (Blase \& Blase, 2000). On the first issue, it is important the School Principal encourages dialogue with teachers on issues related to learning and professional practices. A School Principal aiming to facilitate dialogue is good to follow strategies such as submission of proposals, providing feedback, modeling, seeking views, advice and giving rewards. Regarding the second issue, promoting professional development of teachers, it is important that the School Principal pursues strategies related to the need for knowledge of issues connected with teaching and learning, with the support of the cooperation between teachers, the development of relationships between teachers by encouraging and supporting redesign of programs, applying the principles of adult learning for learning and professional development in the decision-making process (Blase \& Blase, 2000). Teachers' training should be governed by certain principles, such as being perceived as part of their professional development (Papanaoum, 2003). It is important to figure out that learning in the workplace is a major part of adult education in their lifetime (Boud \& Middleton, 2003). When teachers are encouraged to develop by training new skills, they feel more creative, remove the monotony and negative emotions resulting from work and become more effective (Supovitz \& Turner, 2000). A recent research has shown out that the positive attitude of School Principal contributes to professional development of teachers with little experience, less than five years (Delvaux et al., 2013).

Effective School Principle-leader affects development of human resources in school. First, he promotes intellectual stimulation, encourages feedback and causes school staff to examine various data about work by reviewing how it can be executed. He/she also provides information and resources to help teachers identify gaps between current and desired 
practices and activates their conquered knowledge to understand the need for changes. Secondly, he/she provides personalized support. For successful changes in educational process the change is required from those who are involved in it. Successful school Principal-leader shows interest in teaching staff and cares for their needs and feelings; provides incentives and supports structures that promote changes as opportunities for learning and he monitors the path to improvement. Finally, he provides a suitable model. The School Principal-leader brings examples to teaching staff that are consistent with the vision and goals of the school unit. By modeling desires and actions a School Principal reinforces others' beliefs for their abilities and increases their enthusiasm for change (Leithwood \& Riehl, 2005). Most of work in schools is carried out by the efforts of people. A school which offers excellent education requires excellent teachers. The profile of excellent teacher entails on the one hand the existence of necessary knowledge (e.g. knowledge of the teaching subject), the development of cognitive skills and abilities, knowledge about school, teaching, learning and on the other the existence of fundamental personal qualities, attitudes and skills, such as inspiration, creativity, investigative capacity, commitment to work (Papanaoum, 2005). Incentive policy of School Principal can make teachers better. Making best teachers and schools are better. Training teachers can contribute in this direction (Berry et al., 2008; Burkhardt \& Schoenfeld, 2003) when it covers requirements related to philosophy and politics of teaching profession, and modern scientific data about education and teaching staff (Papanaoum 2008, pp. 54-61).

\section{Conclusion}

Studying the leadership literature and specific the educational leadership literature, we realize that different leadership styles are associated with the effectiveness of schools. In most a successful School Principal-leader has to do with changes related to school life and the maintenance of these changes, distribution of responsibilities or even involving teaching staff in decisions related to school subjects and social control based on strong professional identity, ability, cooperation and trust. The research shows that a School Principal that follows an incentive policy to motivate teaching staff has to involve them in professional learning activities and teaching practices related to their professional development, needs to encourage dialogue with them on issues related to educational process. Also, it is clear that a School Principal affects the development of the teaching staff in the school unit that he/she manages. First, the leader provides information, promotes mental stimulation, and encourages feedback. Second, the Director provides individualized support, showing interest in the teaching staff. Third, the Principal provides a suitable model, bringing examples to educational staff that are consistent with the vision and goals of the school unit. Also, strategies of a School Principal affect the efficacy and daily performance of teaching staff in school unit by an incentive policy. A School Principal-leader plans, motivates, controls, sets clear, time-based, academically focused goals in order to get the school moving in the desired direction. By supporting teachers to what their professional development needs brings positive attitude and affects work in the classroom. School Principal and teachers can with their active collaboration around instructional matters enhance the quality of teaching and their pupils' performance.

\section{Acknowledgement}

I would like to acknowledge the real interest, motivation, right guidance and companionship of M.sc. Anastasia Tsiountou, School Principal of $3^{\text {rd }}$ Gymnasium at Karditsa/Thessaly/Greece (from September 2011 to present) for her important role to my professional development.

\section{References}

Ash, R. \& Persall, J. (2000). The principal as chief learning officer: Developing teacher leaders. NASSP bulletin, 84(616), 15-22.

Bamburg, J. \& Andrews, R. (1991). School goals, principals, and achievement. School Effectiveness and School Improvement, 2(3), 175-191.

Bass, B. (1985). Leadership and performance beyond expectations. Free Press: Collier Macmillan.

Berry, B., Smylie, M. \& Fuller, E. (2008). Understanding teacher working conditions: A review and look to the future. Report prepared for the Spencer Foundation. Hillsborough, NC: Center for Teaching Quality.

Birasnav, M., Rangnekar, S. \& Dalpati, A. (2010). Transformational leadership and human capital benefits: The role of knowledge management. Leadership \& Organization Development Journal, 32, 106-126.

Blase, J. \& Blase, J. (2000). Effective instructional leadership: Teachers' perspectives on how principals promote teaching and learning in schools. Journal of Educational Administration, 38(2), 130-141.

Bonn, I. \& Fisher, J. (2011). Sustainability: the missing ingredient in strategy. Journal of business strategy, 32(1), 5-14.

Bossert, S., Dwyer, D., Rowan, B. \& Lee, G. (1982). The instructional management role of the principal. Educational Administration 
Quarterly, 18(3), 34-64.

Boud, D. \& Middleton, H. (2003). Learning from others at work: communities of practice and informal learning. Journal of workplace learning, 15(5), 194-202.

Burkhardt, H. \& Schoenfeld, A. (2003). Improving Educational Research: Toward a More Useful, More Influential, and Better-Funded Enterprise. Educational Researcher, 32(9), 3-14.

Carey, W., Philippon, D., \& Cummings, G. (2011). Coaching models for leadership development: An integrative review. Journal of Leadership Studies, 5(1), 51-69.

Clemson-Ingram, R. \& Fessler, R. (1997). Innovative programs for teacher leadership. Action in Teacher Education, 19(3), 95-106.

Coleman, P. \& Collinge, J. (1991). In the Web: Internal and External Influences Affecting School Improvement. School Effectiveness and School Improvement: An International Journal of Research, Policy and Practice, 2(4), 262-285.

Dan-Shang, W., \& Chia-Chun, H. (2013). The effect of authentic leadership on employee trust and employee engagement. Social Behavior \& Personality: An International Journal, 41, 613-624.

Delvaux, E., Vanhoof, J., Tuytens, M., Vekeman, E., Devos, G. \& Van Petegem, P. (2013). How may teacher evaluation have an impact on professional development? A multilevel analysis. Teaching and Teacher Education, 36, 1-11.

De Cremer, D. (2007). Emotional Effects of Distributive Justice as a Function of Autocratic Leader Behavior1. Journal of Applied Social Psychology, 37(6), 1385-1404.

De Meuse, K., Dai, G., \& Wu, J. (2011). Leadership skills across organizational levels: A closer examination. The Psychologist-Manager Journal, 14(2), 120-139.

Eagly, A., Johannesen-Schmidt, M. \& Van Engen, M. (2003). Transformational, transactional, and laissez-faire leadership styles: a metaanalysis comparing women and men. Psychological bulletin, 129(4), 569-591.

Evetts, J. (2005) The management of professionalism: a contemporary paradox, paper presented at the ESRC TLRP Seminar Series Changing Teacher Roles, Identities and Professionalism, King's College London, 19 October.

Frost, D. \& Durrant, J. (2003). Teacher leadership: Rationale, strategy and impact. School Leadership \& Management, 23(2), $173-186$.

Geijsel, F., Sleegers, P., Leithwood, K. \& Jantzi, D. (2003). Transformational leadership effects on teachers' commitment and effort toward school reform. Journal of Educational Administration, 41, 228-256.

Goodnight, R. (2004). Laissez-faire leadership. The Economic Journal, 98(392), 755-771.

Gray, J. (1990). The quality of schooling: frameworks for judgment. British Journal of Educational Studies, 38(3), 204-223.

Hallinger, P. \& Murphy, J. (1986). The social context of effective schools. American Journal of Education, 94(3), 328-355.

Hallinger, P. (2003). Leading educational change: Reflections on the practice of instructional and transformational leadership. Cambridge Journal of education, 33(3), 329-352.

Hallinger, P. (2005). Instructional leadership and the school principal: A passing fancy that refuses to fade away. Leadership and policy in schools, 4(3), 221-239.

Harris, A. (2003). Teacher leadership as distributed leadership: heresy, fantasy or possibility?. School leadership \& management, 23(3), 313-324.

Hoffman, B., Bynum, B., Piccolo, R. \& Sutton, A. (2011). Person-organization value congruence: How transformational leaders influence work group effectiveness. Academy of Management Journal, 54, 779-796.

Kalyani, M. \& Sahoo, M. (2011). Human resource strategy: a tool of managing change for organizational excellence. International Journal of Business and Management, 6(8), 280-286.

Kawar, T. (2012). The impact of leadership on student learning. International Journal of Business \& Social Science, 3, 319-322.

Kelley, R., Thornton, B. \& Daugherty, R. (2005). Relationships between measures of leadership and school climate. Education Indianapolis Then Chula Vista, 126(1), 17-28.

Kirkpatick, S. \& Locke, E. (1991). Leadership: do traits matter?. The Executive, 5(2), 48-60.

Lambert, L. (2002). A framework for shared leadership. Educational Leadership, 59(8), 37-40.

Leithwood, K. \& Riehl, C. (2005). What we know about successful school leadership. In Firestone, W. \& Riehl, C. (Eds.). A new agenda: Directions for research on educational leadership (pp. 22-47). New York, NY: Teachers College Press.

Leithwood, K. \& Sleegers, P. (2006). Transformational school leadership: Introduction. School Effectiveness and School Improvement, $17,143-144$.

Limbare, S. (2012). Leadership styles \& conflict management styles of executives. Indian Journal of Industrial Relations, 48(1), 172-180.

Marks, H. \& Printy, S. (2003). Principal leadership and school performance: An integration of transformational and instructional leadership. Educational administration quarterly, 39(3), 370-397.

Mortimore, P. (1988). School matters. University of California Press.

Nielsen, R., Marrone, J. \& Slay, H. (2010). A new look at humility: Exploring the humility concept and its role in socialized charismatic leadership. Journal of Leadership \& Organizational Studies, 17(1), 33-43.

Nguni, S., Sleegers, P. \& Denessen, E. (2006). Transformational and transactional leadership effects on teachers' job satisfaction, organizational commitment, and organizational citizenship behavior in primary schools: The Tanzanian case. School Effectiveness and School Improvement, 17, 145-177.

Papanaoum, Z. (2003). The teaching profession: a theoretical and empirical approach. Athens: Typothito. (in Greek)

Papanaoum, Z. (2005). The role of teacher training in professional development: Why, When, How;. In Bagakis, G. (Ed.). Training and Professional Development of Teaching (pp.82-91). Athens: Metexmio. (in Greek)

Papanaoum, Z. (2008). For a Better School: The role of teacher training. In Vlachos, D. (Ed). Quality Education and the Greek School 
(pp. 54-61). Athens: Pedagogical Institute. (in Greek)

Parsons, T. (2008). The School Class as Social System. In Ballantine, J. \& Spade, J. (Eds.). Schools and society: A sociological approach to education (3rd ed., pp. 80-85). California: Pine Forge Press.

Pawar, D. (2014). Styles of Leadership. International Journal of Research in all Subjects in Multi Languages, 2(7), 12-14.

Pellegrini, E. \& Scandura, T. (2008). Paternalistic leadership: A review and agenda for future research. Journal of Management, 34(3), 566-593.

Peterson, R. (1997). A directive leadership style in group decision making can be both virtue and vice: Evidence from elite and experimental groups. Journal of Personality and Social Psychology, 72(5), 1107-1121.

Riggio, R., Bass, B. \& Smith Orr, S. (2003). Transformational Leadership in Nonprofit Organizations. In Riggio, R. \& Smith Orr, S. (Eds.). Improving leadership in nonprofit organizations (pp. 49-62). San Francisco: John Wiley \& Sons.

Ross, J. \& Gray, P. (2006). Transformational leadership and teacher commitment to organizational values: The mediating effects of collective teacher efficacy. School Effectiveness and School Improvement, 17, 179-199.

Sahaya, N. (2012). A learning organization as a mediator of leadership style and firms' financial performance. International Journal of Business \& Management, 7, 96-113.

Saitis, Ch. (2008). Educational policy and administration. Athens: OAED (in Greek)

Scheibehenne, B., Rieskamp, J. \& Gonzalez-Vallejo, C. (2011). Cognitive models of choice: Comparing decision field theory to the proportional difference model. Cognitive Science: A Multidisciplinary Journal, 33(5), 911-939.

Senge, P. (2006). The Fifth Discipline: The Art and Practice of the Learning Organization. Broadway Business.

Siatira, St., Sdrolias, L., Aspridis, G. \& Papadimopoulos, I. (2014). The Effect of the School Internal Environment of Secondary Education on Daily Work of Teaching Staff: A Systemic Approach. Mediterranean Journal of Social Sciences, 5(13), 244-251.

Smith, D. \& Tomlinson, S. (1990). The school effect: A study of multi racial comprehensives. School Effectiveness and School Improvement: An International Journal of Research, Policy and Practice, 1(1), 81-86.

Somech, A. (2005). Directive versus participative leadership: Two complementary approaches to managing school effectiveness. Educational Administration Quarterly, 41(5), 777-800.

Supovitz, J. \& Turner, H. (2000). The Effects of Professional Development on Science Teaching Practices and Classroom Culture. Journal of Research in Science Teaching, 37(9), 963-980.

Teddlie, C., Kirby, P. \& Stringfield, S. (1989). Effective versus ineffective schools: Observable differences in the classroom. American Journal of Education, 221-236.

Thiagarajan, K. (2003). Missionary Leadership. In Riggio, R. \& Smith Orr, S. (Eds.). Improving leadership in nonprofit organizations (pp. 39-48). San Francisco: John Wiley \& Sons.

Thoonen, E., Sleegers, P., Oort, F., Peetsma, T. \& Geijsel, F. (2011). How to improve teaching practices the role of teacher motivation, organizational factors, and leadership practices. Educational Administration Quarterly, 47(3), 496-536.

Van Vugt, M., Jepson, S., Hart, C. \& De Cremer, D. (2004). Autocratic leadership in social dilemmas: A threat to group stability. Journal of Experimental Social Psychology, 40(1), 1-13.

Vroom, V. (1964). Work and motivation. San Francisco, CA: Jossey-Bass.

Weindling, D. (1989). The process of school improvement: some practical messages from research. School Organization, 9(1), 53-64.

Wright, B., Moynihan, D. \& Pandey, S. (2012). Pulling the levers: Transformational leadership, public service motivation, and mission valence. Public Administration Review, 72(2), 206-215.

Zhu, W., Sosik, J., Riggio, R. \& Yang, B. (2012). Relationships between transformational and active transactional leadership and followers' organizational identification: The role of psychological empowerment. Journal of Behavioral \& Applied Management, $13,186-212$. 